\title{
MEMBACA DAN MEMAKNAI MAZMUR RATAPAN 12 DENGAN METODE BACA GALI ALKITAB
}

\author{
Hasahatan Hutahaean ${ }^{1}$, Elirani Gea ${ }^{2}$, Adarsan Simarmata ${ }^{3}$ \\ Sekolah Tinggi Teologi Sumatera Utara ${ }^{1,2}$, \\ Sekolah Tinggi Teologi Gereja TUHAN di Indonesia ${ }^{3}$ \\ hasea2014@gmail.com
}

\begin{abstract}
One type of psalm is Lament. Psalms of Lament sung with weeping, weeping driven by the psalmist's sorrow. David wrote many psalms where one of them is lamentation in Psalm 12. In this article the psalmist experienced a change of mood (feeling) from lamenting, joyful hope then again lamenting. The research in this paper used a qualitative approach to library research methods. Literature research requires a study of related literature to guide researchers to achieve the research objectives of the data taken based on selected books. While the interpretation to find the meaning of the text of the Research Team uses the method of Reading the Bible (BGA). The methods of BGA are simple but practice interpretation that was designed initially for Christian quiet times. After Psalm 12 interpreted, the Research Team founded that the psalmist was still lamenting over the situation around him. Even though the psalmist experienced joy because God will save, but the wicked are still there and rottenness still arises among the sons of men. Because God works not based on the presence or absence of the wicked and rottenness among the children of men.
\end{abstract}

Keywords: $\quad$ Psalm 12, lament psalms, BGA methods, genre, poetry

Abstrak: $\quad$ Salah satu jenis mazmur adalah Ratapan. Mazmur Ratapan dinyanyikan dengan meratap, menangis didorong oleh kesedihan yang dialami pemazmur. Daud menuliskan banyak mazmur dimana salah satunya adalah ratapan pada Mazmur 12. Dalam tulisan ini pemazmur mengalami perubahan mood (perasaan) dari meratap, sukacita berpengharapan kemudian kembali lagi meratap. Penelitian yang digunakan dalam tulisan ini adalah pendekatan kualitatif dengan meteode penelusuran kepustakaan. Sedangkan penafsiran untuk menemukan makna teks Tim Peneliti menggunakan metode Baca Gali Alkitab (BGA). Metode BGA adalah cara penafsiran yang sederhana namun praktis yang dirancang awalnya untuk saat teduh orang kristen. Temuan Peneliti dari penafsiran Mazmur 12 berupa perasaan pemazmur yang masih meratap atas situasi sekitarnya. Meski pemazmur sempat mengalami sukacita karena Allah akan menyelamatkan, namun orang-orang fasik masih ada dan kebusukan tetap muncul di antara anak manusia. Karena karya Allah tidak bergantung pada ada atau tidaknya orang-orang fasik dan kebusukan di antara anak-anak manusia.

Kata kunci: Mazmur 12, mazmur ratapan, metode BGA, genre, puisi

\section{PENDAHULUAN}

Mazmur adalah kitab pujian dan kitab doa umat Israel Perjanjian Lama dan umat Kristen di era Perjanjian Baru, yang ditulis dalam bentuk puisi. Mazmur 
terdiri dari 150 nomor pujian atau doa yang menceritakan kisah kasih Allah terhadap diri pamazmur, yang berasal dari perjalanan hidupnya pribadi, secara suku atau bangsa. Adakalanya pemahaman iman sejalan dengan pengalaman iman, maka timbullah ucapan syukur, pujian, keyakinan dan pengajaran (hikmat). Allah memakai pergumulan orang percaya demi meneguhkan iman orang beriman lainnya. ${ }^{1}$ Kadang juga pengalaman tidak sejalan dengan pemahaman, maka timbul mazmur keluhan atau ratapan, permohonan. Penggunaan pengalaman kehidupan sehari-hari menjadi salah satu karakter penulisan Mazmur. Ada juga pemakaian satu gambaran dengan berbagai simbol atau kedukaan serta tingkat sosial di masyarakat. Misalnya pekerjaan Gembala dilambangkan sebagai pelindung dan kerap memperhatikan yang lemah. ${ }^{2}$ Dalam kisah-kisah penderitaan di kitab Mazmur, kontras fasik dengan orang benar, pemurah dan kikir atau bahagia dan menderita acapkali ditemukan. Samgar Setia Budhi menyatakan penderitaan orang benar dan kemakmuran orang fasik seringkali menjadi persoalan bagi orang yang beriman. ${ }^{3}$ Dalam pemaparan kitab Mazmur isu kontras penderitaan umat Allah atau orang benar terhadap kesuksesan dan kemakmuran orang fasik ditarik dari zaman Alkitab dan masih relevan didiskusikan hingga masa kini. Contoh tokoh Ayub, Yeremia (Yer. 11:8-12:6), dan pemazmur (Mzm. 12, 13, 15, 37, 73) yang menggambarkan situasi kontras ini.

John Balchim menyatakan bahwa pemazmur memiliki keyakinan bahwa Allah adalah adil, karena itu Allah akan menghukum orang-orang fasik dan orang

\footnotetext{
1Martus Adinugraha Maleachi, "Karakteristik dan Berbagai Genre dalam Kitab Mazmur," Veritas : Jurnal Teologi dan Pelayanan 13, no. 1 (2012): 121, https://doi.org/10.36421/veritas.v13i1.250.

2David T. Adamo, "Reading Psalm 23 in African Context," Verbum et Ecclesia 39, no. 1 (2018): 3, https://doi.org/10.4102/ve.v39i1.1783.

${ }^{3}$ Samgar Setia Budhi, "Eksegesis Mazmur 73: Pergumulan Orang Benar Tentang Kemakmuran Orang Fasik," HUPERETESS 1, no. 1 (2019): 2.
} 
berdosa lainnya serta pada akhirnya Allah akan membenarkan serta memulihkan umatNya. ${ }^{4}$ Jika membaca kitab-kitab mazmur bayangan hal-hal praktis akan membantu untuk menyelami gaya kepenulisannya. Gaya penulisan pada Perjanjian Baru memberi banyak ruang dalam pengutipan Mazmur ketika ingin menggambarkan bahwa Allah sanggup melakukan banyak hal kepada orang-orang yang percaya kepadaNya. ${ }^{5}$

Sebagai sebuah tulisan kesusastraan, pemahaman terhadap tulisan-tulisan nyanyian berbentuk puisi tentu tidak terhindarkan. Untuk Mazmur 12 Smoak $^{6}$ dalam penelitiannya mengungkap bahwa berpendapat bahwa frasa misterius blyl dalam ayat 7 harus dipahami sebagai referensi untuk jenis-jenis tungku peleburan Zaman Besi, yang sebagian tenggelam ke tanah.

Selain itu doa-doa dalam Mazmur bisa bersifat pribadi (berkaitan dengan keselamatan pribadi, kesembuhan dari sakit) kadang juga bersifat komunal dalam ibadah, kadang bahkan nasional. Doa-doa Mazmur dilantunkan dalam ibadahibadah tertentu seperti penobatan raja, penahbisan bait Allah, dan lainya. Kisahkisah iman pribadi, komunal dan secara nasional ataupun tentang raja dapat dirangkum sebagai kosepsi iman Perjanjian Lama yang biasanya menunjukkan sikap eksistensial yang menyangkut seluruh pribadi kepada Allah dalam keilahianNya, ${ }^{7}$ sebagai dasar yang dapat diandalkan dalam kehidupan sesungguhnya. Untuk menemukan makna sesungguhnya dari teks Alkitab, tentu dibutuhkan kerja yang tekun dengan memperhatikan kaidah penafsiran.

4John Balchin dkk., Intisari Alkitab Perjanjian Lama (Jakarta: Scripture Union Indonesia, 2016), 188. 5Balchin dkk., 205 Misalnya Mazmur 2 dalam KPR 4:25-26; 13:33; Mazmur 18:49 dalam Rom.15:9. Mazmur 110 dalam Mark.12:36; 14:62 atau 16:19. Serta perikop-perikop lainnya dalam Perjanjian Baru. ${ }^{6}$ Jeremy D. Smoak, "Amuletic inscriptions and the background of YHWH as guardian and protector in Psalm 12," Vetus Testamentum 60, no. 3 (2010): 421-432, https://doi.org/10.1163/156853310X504856. 2012), 36.

${ }^{7}$ Georg Kirchberger, Allah Menggugat Sebuah Dogmatik Kristiani, Kedua (Maumere: Ledalero, 
Pemahaman yang benar tentang Allah dan kehendakNya melalui penelusuran Alkitab sangat diperlukan untuk tiba pada hasrat biblis ini. ${ }^{8}$ Pembaca Alkitab masa pada kini harus kembali kepada Alkitab sebagai pedoman hidup orang Kristen. Nitis Harsono memberi pencerahan tentang penderitaan pada masa Alkitab bahwa penghukuman dan siksaan bukanlah dalam rangka pemusnahan bagi umat Allah, namun bisa saja sebagai pembaharuan perjanjian. ${ }^{9}$ Allah tetap memberi perhatian kepada umat-Nya, demikian pula Allah hendak menjadikan mereka supaya tetap mengenal dan hormat pada Allah-Nya. Allah masih terus melangsungkan karya penyelamatan umat pilihanNya (historica sacra) demi mewujudnyatakan rencana-Nya atas dunia milik-Nya. Pemilihan terhadap Israel tetap terus bagi Allah dan tidak terhalang oleh karena pelanggaran-pelanggaran umat semata.

Tulisan ini akan menelusuri kedalaman makna yang terdapat dalam Mazmur 12, serta keindahan dari sebuah Mazmur patut diperhatikan disamping menemukan arti yang dikandungnya. ${ }^{10}$ Fokus kepada Mazmur 12 salah satunya karena tidak ada pembahasan yang khusus terhadapnya sejauh ini kecuali dari salah satu bahasan dalam buku Arman Barus ${ }^{11}$ dan David T Adamo. ${ }^{12}$ Meski dalam bentuk tafsiran-tafsiran dan Commentary tentu dapat ditemukan namun belum memberikan outcome berdasarkan pada genre Mazmur 12 sebagai genre Ratapan. Peneliti berkeyakinan ada cerita yang sangat berarti bagi pembaca di dalam Mazmur 12 sehingga pemazmur merasa pesimis dengan berujar,

8Budhi, "Eksegesis Mazmur 73: Pergumulan Orang Benar Tentang Kemakmuran Orang Fasik," 2. ${ }^{9}$ Nitis Harsono, "Tugas Manusia dalam Dunia Milik Tuhan," Fidei: Jurnal Teologi Sistematika dan Praktika 3, no. 1 (2020): 118, https://doi.org/10.34081/fidei.v3i1.95. ${ }^{10}$ Maleachi, "Karakteristik dan Berbagai Genre dalam Kitab Mazmur," 123.

${ }^{11 A r m a n d ~ B a r u s, ~ M e n g e n a l ~ T u h a n ~ M e l a l u i ~ P e n d e r i t a a n ~(J a k a r t a: ~ S c r i p t u r e ~ U n i o n ~ I n d o n e s i a, ~ 2015), ~}$ 93-106.

${ }^{12}$ Adamo, "Reading Psalm 23 in African Context." 
“Tolonglah kiranya, TUHAN, sebab orang saleh telah habis." Bagaimana pembaca sekarang memaknai kata-demi kata dalam Mazmur 12 dengan janji Tuhan akan memberi keselamatan bagi orang yang menghauskannya. Apakah yang akan diberikan melalui penafsiran dengan menggunakan metode Baca Gali Alkitab $^{13}$ (BGA) akan memberikan hasil yang tepat. Perlu diketahui bahwa Metode Baca Gali Alkitab adalah salah satu metode penggalian yang sederhana sesuai genre dari Alkitab. Peneliti menggunakan metode tersebut dalam tulisan ini karena metode yang sederhana, namun memiliki kekuatan dalam mengeksplorasi makna teks dengan tepat. Sehingga pembaca akan lebih mudah memahami hasil penafsiran dari teks yang digali.

\section{METODE}

Metode Metode yang digunakan dalam penelitian ini adalah metode penelitian kepustakaan (library research), yang tergolong penelitian kualitatif. ${ }^{14}$ Penelitian kepustakaan dalam tulisan ini akan menggunakan jenis analisa buku teks. Yakni memerika buku-buku terkait yang bersifat evaluasi untuk mengetahui tehnologi mutakhir. James menyatakan bahwa library research termasuk penelitian yang sistematis serta ilmiah yang menjadikan literature dan berbagai bacaan lain yang turut menjadi sumber acuan penelitian demi membangun literasi yang mendukung bagi variabel penelitian. ${ }^{15}$ Dengan paparan diatas, peneliti menggunakan pendekatan hermeneutik ${ }^{16}$ sedangkan data terkumpul dianalisa

\footnotetext{
${ }^{13 B}$ Baca. Armand Barus, Baca Gali Alkitab Genre: Mazmur Ratapan, ed. oleh Restu A Santoso (Jakarta: Scripture Union Indonesia, 2019).

${ }^{14}$ Amir Hamzah, Metode Penelitian Kepustakaan, Revisi (Malang: Literasi Nusantara, 2020), 21.

15James Danandjaja, "Metode Penelitian Kepustakaan," Antropologi Indonesia 0, no. 52 (15 Juli 2014): 83, https://doi.org/10.7454/ai.v0i52.3318.

${ }^{16}$ Hamzah, Metode Penelitian Kepustakaan, 32.
} 
dengan metode analisis semiotik. ${ }^{17}$ Alur penulisan dimulai dengan pemaparan pembacaan nas kemudian menafsirkannya dengan metode BGA lalu pada bagian akhir diberikan penerapan atas temuan makna dari Mazmur 12. Karena itu pada bagian awal akan dipaparkan apa itu metode BGA dan prosedur analisis data.

\section{HASIL}

Penelitian ini memberikan khazanah yang baru dalam membaca dan memaknai teks Alkitab khususnya genre ratapan pada kitab Mazmur. Dalam membaca genre kitab ratapan seseorang dituntun untuk menemukan pengelolaan perasaan pemazmur. Pada Mazmur 12 ditemukan olah rasa yang dinamis karena terjadinya perubahan mood dalam diri pamazmur. Pemazmur masih mengalami pergumulan pada bagian akhir (ayat 9). Ayat terakhir ini menunjukkan bahwa pergumulan, masalah seseorang kadangkala masih saja belum berlalu (selesai) meski penyerahan kepada Allah telah dilakukan. Dari Mazmur 12 dengan pembacaan dan mencari makna dengan metode BGA pembaca diajar bahwa seseorang perlu mengenal TUHAN lebih dekat dengan cara yang benar di dalam pemahaman yang sesuai dengan isi hati TUHAN. Pada ayat 6 hingga ayat 7 pemazmur memberikan titik terang kepedulian Allah atas derita yang diratapinya pada ayat 1 sampai ayat 5 . Namun di ayat 9 orang fasik ternyata masih ada di mana-mana dan kebusukkan masih ditemukan diantara anak manusia.

Tidak ubahnya dengan situasi terkini di Indonesia dan seluruh dunia yakni virus covid-19 belum berlalu sementara vaksin untuknya belum kunjung ditemukan. Apakah Allah tidak mendengar keluhan banyak keluarga yang kehilangan anggota sanak familinya? Dengan korban lebih 100 dokter di 
Indonesia adakah Allah sungguh berpaling dari (setidaknya) seluruh keluarga besar dokter di Indenesia? Dalam pespektif pembacaan Mazmur 12 ditemukan bahwa pengenalan akan TUHAN serta teguh memegang janjiNya menjadi perhatian umat (pembaca) masa kini. Bahkan hingga satu masa akhir hayat manusia berujung dan masalah belum menyingkir daripadanya, satu kepastian adalah TUHAN yang Maha Esa tetap menjaga.

\section{PEMBAHASAN}

Penafsiran terhadap Alkitab menurut penulis adalah proses memperoleh makna dari teks yang ditulis pada masa dan konteks penulis, agar pembaca sekarang memaknai dengan tepat serta beroleh tuntunan praktis yang benar dalam kehidupannya menjalin relasi dengan Tuhan, si Pemilik Firman. Vanhoozer menekankan bahwa penafsiran tidak saja penerapan kaidah hermeneutika namun tidak boleh melupakan pada fokus Allah yang penuh kasih dan berdaulat dalam hidup manusia. ${ }^{18}$ Dengan melalui jalan penafsiran yang benar seseorang akan memperoleh makna yang tepat seturut maksud penulisannya pertama kali.

Untuk menemukan maksud teks, penafsiran menuntun seseorang untuk masuk kepada maksud kepenulisan, gaya penulisan (kesusastraan) yang digunakan serta keterkaitan aspek teologis yang saling mengait. Maksudnya temuan teologis pada topik Yesus (Kristologi) misalnya, tidak akan bertentangan dengan pemahaman pada topik eskatologi. Tidak terkecuali bidang teologi dengan teologi praktika. Hasil penafsiran bukan bermaksud untuk menegasikan salah satu diantaranya. Apa yang dimaksud dalam praktis pada masa Alkitab juga tidak menuntun pada sesat praktek pada masa kini. Sebab filosofi dan dasar praktek 
dalam masa penulisan ditelusuri maksud dan tujuannya agar memperoleh makna yang benar untuk diikuti oleh pembaca masa kini. Margaret memberikan keterkaitan tersebut dengan menyatakan bahwa tugas hermeneutika tidak hanya berhenti pada menanyakan maksud penulis bagi pembaca pertama, melainkan juga menanyakan maksud Allah di dalam teks kepada pembaca hari ini. ${ }^{19}$ Sejalan dengan pendapat tersebut, Ongkowidjojo ${ }^{20}$ memaparkan dengan singkat dalam persfektif Theological Interpretation of Scripture, bahwa penafsiran harus menyeluruh dengan memberi porsi yang seimbang antara doktrin dan aplikasi tanpa mengesampingkan kaidah penafsiran yang benar, bukan eisegese.

Scripture Union Indonesia (SUI) menyusun satu rangkaian metode dalam menggali dan memahami nats Alkitab dengan satu metode yang disebut Baca Gali Alkitab (BGA).

\section{Baca Gali Alkitab}

Baca Gali Alkitab (BGA) adalah salah satu metode penggalian Alkitab yang sederhana dan praktis. Metode ini dikembangkan oleh Scripture Union Indonesia (SUI) terdiri dari pertanyaan-pertanyaan berjenjang dengan maksud untuk meneliti semua ayat secara konprehensif sehingga menghasilkan pesan utama dan mudah dipelajari oleh jemaat. ${ }^{21}$ Metode ini diakhiri dengan tantangan

${ }^{19}$ Carmia Margaret, "Pendekatan Interpretasi Teologis Kitab Suci dan Prasuposisi-Prasuposisi Teologis di Baliknya," Veritas: Jurnal Teologi dan Pelayanan 18, no. 2 (2019): 151, https://doi.org/10.36421/veritas.v18i2.330.

${ }^{20}$ Hendry Ongkowidjojo, "Theological Interpretation Of Scripture; Suatu Pengantar," Amanat Agung 9 (1) (2013): 35.

${ }^{21}$ Armand Barus, Hans Wuysang, dan Rimawaty Panjaitan, Panduan Pelatihan Baca Gali Alkitab (Jakarta: Scripture Union Indonesia, 2015), 3. 
atau respons pembaca untuk memperbaiki kehidupan setelah membaca Alkitab.

Adapun langkah dari $\mathrm{BGA}^{22}$ adalah sebagai berikut;

1. Berdoa, mohon pencerahan Roh Kudus. Dengan segenap hati dalam doa, mohon agar Roh-Nya memberikan pencerahan (ilmuninasi).

2. Bacalah, nas yang diberikan pada hari itu. Baca nas berulang sampai meresap.

3. Renungkanlah, dengan dibantu 3 pertanyaan

a) Apa saja yang kubaca? Menemukan tokoh, tempat, waktu, lalu membahasakan kembali apa-apa yang ada dalam nas.

b) Apa pesan Allah yang kudapat? Jenis pesan berupa; pelajaran, perintah, peringatan, janji, dan teladan. Tidak semua jenis pesan harus ada pada semua nas yang digali.

c) Apa responsku? Hal-hal spesifik dalam hidup yang disoroti. Itu dimungkinkan oleh horizon-horizon mana yang lebih "penting dan genting" atau urgen bagi si pembaca. Respons berupa: ucapan syukur, doa, pengakuan dosa dan tekad.

4. Bandingkanlah dengan Santapan Harian.

5. Berdoa, mohon Allah memberdayakan untuk melakukan firman-Nya ${ }^{23}$

Sebagai sebuah kesusastraan, maka tiap-tiap tulisan dalam Alkitab harus didekati dan dipahami sesuai genrenya. Penafsiran dengan mengikuti genre menurut hemat penulis akan memberi kemudahan dalam menemukan maksud tulisan. Sebab genre telah menjadi seperti pengklasifikasian terhadap jenis tulisan yang sama. ${ }^{24}$ Kitab Mazmur masuk dalam genre puisi. ${ }^{25}$ Sesuai dengan bentuk sastra puisi, tujuan utama belajar mazmur bukan untuk menemukan pengajaran teologis, karena mazmur ditulis terutama mengungkapkan pengalaman dan perasaan beriman yang dipadankan dengan pemahaman iman sebagai suatu pengungkapan yang emosional dan mendalam. ${ }^{26}$ Jadi yang ada adalah refleksi

22Barus, Wuysang, dan Panjaitan, 8.

${ }^{23}$ Langkah dari Metode BGA ini juga terdapat dalam; Redaksi Scripture Union Indonesia, "Santapan Harian" (Jakarta: Scripture Union Indonesia, 2020), 1 Hasil tafsiran didalamnya sederhana dan mudah untuk dimengerti baik dalam pesan maupun respons yang ditawarkan untuk dilakukan pembaca.

${ }^{24}$ Grant R. Osborne, Spiral Hermeneutika: Pengantar Komprehensif bagi Penafsiran Alkitab (Surabaya: Momentum, 2012), 207.

250sborne, 259.

26 Osborne, 270. 
terhadap teologi, bukan teologi itu sendiri. Artinya Mazmur merupakan tulisan untuk memberi refleksi dari pesan tentang Allah, kehendakNya dan bagaimana harusnya umat itu hidup. Mazmur bukan untuk memberi risalah topic-topik dalam teologi itu sendiri. Namun bukan berarti pembaca tidak dapat menggali pemahaman teologi pemazmur, hanya bukan itu tujuan utamanya. Pembacaan dengan metode BGA mengakomodir sisi-sisi hermeneutis dalam masing-masing genre, ${ }^{27}$ agar penggunaannya dalam saat teduh tetap dinamis dan kian tekun karena keindahan teks dapat ditelusuri.

Membaca mazmur seolah mengidentifikasi diri dengan si pemazmur, perasaan-perasaannya, pengalaman-pengalamannya dan baru pemahamanpemahamannya tentang karya Tuhan. Jika merujuk kepada John Drane, salah satu alasannya ialah kebanyakan kitab mazmur ini memiliki akar dalam ibadah di Bait Allah Salomo dan sangat mungkin di tempat ibadah lokal. ${ }^{28}$ Jadi pembaca mazmur dengan sendirinya mengidentifikasikan diri dengan si pemazmur dalam mengapresiasi apa yang Tuhan sudah perbuat atas dirinya. Pengalaman dan perasaan pemazmur bisa menjadi pengalaman dan perasaan pembaca pada masa kini. Sebab itu, dalam memahami kitab Mazmur salah satu langkah yang menentukan dalam penemuan maksud teks adalah menemukan perasaan ( mood) pemazmur.

Langkah-langkah Tafsir metode BGA pada langkah ketiga Renungkanlah dengan butir a) apa saja yang kubaca, maka didapati seperti berikut:

Tabel 1 Langkah-langkah Tafsir langkah ketiga Renungkanlah dengan butir a) apa saja yang kubaca

\footnotetext{
${ }^{27}$ Hasahatan Hutahaean, Pangimpola Na; Pemahaman Nats-nats Almanak Dengan Pendekatan Metode BGA (Medan: Prodi Teologi STTSU, 2017), 4.

28John Drane, Memahami Perjanjian Lama III, ed. oleh Barnabas Ludji, Ketiga (Jakarta: Scripture Union Indonesia, 2017), 96.
} 


\begin{tabular}{|c|c|c|c|}
\hline Pertama & Kedua & Ketiga & Keempat \\
\hline $\begin{array}{l}\text { Tentuka } \\
\text { n genre } \\
\text { Mazmur } \\
\text { tersebut: } \\
\text { genre } \\
\text { utama } \\
\text { dan } \\
\text { genre- } \\
\text { genre } \\
\text { lain } \\
\text { yang } \\
\text { bisa } \\
\text { dideteksi } \\
\text {. Di } \\
\text { dalamny } \\
\text { a juga } \\
\text { diidentifi } \\
\text { kasi } \\
\text { kesejajar } \\
\text { an yang } \\
\text { ada }\end{array}$ & $\begin{array}{l}\text { Tentukan } \\
\text { mood/suasana } \\
\text { hati dan } \\
\text { perubahan } \\
\text { suasana hati } \\
\text { Mazmur } \\
\text { tersebut, } \\
\text { misalnya dari } \\
\text { sedih ke marah } \\
\text { ke syukur dan } \\
\text { lainya. } \\
\text { Perubahan } \\
\text { mood } \\
\text { pemazmur bisa } \\
\text { saja terjadi } \\
\text { ketika adanya } \\
\text { peralihan dari } \\
\text { misalnya } \\
\text { penindasan } \\
\text { berubah ke } \\
\text { penyelamatan } \\
\text { atau sebaliknya }\end{array}$ & $\begin{array}{l}\text { Tentukan } \\
\text { alasan } \\
\text { suasana hati } \\
\text { tersebut, } \\
\text { cari hal } \\
\text { yang } \\
\text { mendasar } \\
\text { secara } \\
\text { teologis } \\
\text { yang } \\
\text { memungkin } \\
\text { kan kita } \\
\text { memahami } \\
\text { suasana hati } \\
\text { dan } \\
\text { perubahann } \\
\text { ya. }\end{array}$ & $\begin{array}{l}\text { Perhatikan penggambaran } \\
\text { seperti metafora dan paralelisme } \\
\text { yang dipakai supaya tidak } \\
\text { terjebak kepada penafsiran yang } \\
\text { berlebihan atau bertele-tele } \\
\left(\text { Band. Drane }{ }^{30} \text { ). Misalnya }\right. \\
\text { pepohonan yang subur dalam } \\
\text { Mazmur } 37 \text {, menurut Botha }{ }^{31} \\
\text { sebagai gambaran tanaman yang } \\
\text { subur di tanah yang dijanjikan } \\
\text { Bapa Yahweh seturut yang } \\
\text { tertulis di Torah. Pada genre } \\
\text { hikmat kitab Ayub, gambaran } \\
\text { hewan juga diberikan dalam } \\
\text { berbagai kesempatan. Menurut } \\
\text { Wicaksono pemakaian gambaran } \\
\text { hewan tersebut bagi Ayub agar } \\
\text { Ayub menyadari sifat-sifat Allah } \\
\text { yang tidak terbatas dan tidak } \\
\text { terkalahkan. }{ }^{32} \text { Bagian ini juga } \\
\text { mengungkap apa saja yang kita } \\
\text { baca tentang TUHAN }\end{array}$ \\
\hline
\end{tabular}

Mazmur 12 adalah jenis Ratapan (lament), karena itu harus ditelaah dengan prinsip-prinsip yang ditentukan dalam prinsip penggalian genre Mazmur Ratapan. Arman Barus menyatakan bahwa Mazmur Ratapan adalah pemadatan rangkaian kata-kata yang memuat permohonan atau permintaan. ${ }^{33}$ Mazmur Ratapan merupakan pergumulan paling realistis dari pengalaman kefanaan manusia yang dirasakan tidak sinkron dengan pemahaman imannya. Misalnya pemahaman iman

\footnotetext{
${ }^{29}$ Osborne, Spiral Hermeneutika: Pengantar Komprehensif bagi Penafsiran Alkitab, 268.

30 Drane, Memahami Perjanjian Lama III, 97.

31 Philippus J. Botha, "Interpreting 'torah' in psalm 1 in the light of psalm 119," HTS Teologiese Studies / Theological Studies 68, no. 1 (2012): 6, https://doi.org/10.4102/hts.v68i1.1274.

${ }^{32}$ Arif Wicaksono, "KETIKA ALLAH 'DIAM': ANALISIS RETORIKA AYUB 39:4-15," Evangelikal: Jurnal Teologi Injili dan Pembinaan Warga Jemaat 2, no. 2 (2018): 143.

33Barus, Mengenal Tuhan Melalui Penderitaan, 26.
} 
Tuhan itu baik, tapi pengalamannya seperti dibiarkan Tuhan menderita. Sumber keluhan menurut si pemazmur bisa berasal dari Tuhan, musuh atau konflik batin/diri sendiri. Mazmur Ratapan kadang mengeluarkan kata-kata keras melawan musuh, yang berupa kutukan (imprecatory psalm), yang menimbulkan kesulitan di dalam membenarkannya.

Dari paparan diatas, maka langkah untuk penggalian genre mazmur ratapan adalah sebagai berikut ${ }^{34}$;

1. Berdoa

2. Baca Alkitab

3. Bagian Renungkanlah yakni menggali Alkitab, terdiri atas pertanyaan Pertama, apa saja yang kubaca dengan;

3.1. Identifikasi kesejajaran

3.2. Identifikasi bahasa gambaran (imagery)

3.3. Apa saja yang keluhan pemazmur yang muncul dalam teks bacaan kita?

3.4. Apa saja perasaan yang muncul dalam teks bacaan Alkitab?

3.5. Apa saja yang kita baca tentang Allah?

3.6. Perubahan suasana teks $(\mathrm{mood})$

Kedua, Adakah pesan yang Allah sampaikan dalam bentuk:

a. Pelajaran/Pengajaran? Pesan jenis ini berupa pemahaman-pemahaman yang baru (insight) terhadap sesuatu yang bukan perintah atau bentuk peringatan bagi pembaca.

b. Perintah Nasihat? Pesan jenis ini berupa perintah yang ditemukan dalam nats. Perlu memahami bahwa perintah yang dimaksud adalah perintah yang berasal dari Allah.

34Barus, Baca Gali Alkitab Genre: Mazmur Ratapan, 6-11. 
c. Peringatan/Larangan? Pesan jenis ini berupa nasihat agar tidak melakukan tindakan, pikiran atau kegiatan-kegiatan yang dilarang oleh Allah/ Bisa juga berupa nasihat dalam bidang etika, sehingga menjadi patokan untuk mengubah tindakan, pikiran atau kegiatan-kegiatan yang telah atau sedang dirancang untuk dikerjakan.

d. Janji? Pesan jenis ini berupa ungkapan yang dapat dimaknai sebagai pesan Allah untuk sesuaitu di masa yang akan datang.

e. Teladan. Pesan jenis ini berupa perilaku dari seseorang (tokoh) yang patut untuk dicontoh pada masa kini. Umumnya teladan perilaku, pikiran, cara-cara melayani, memimpin dari satu tokoh. Namun harus hati-hati terhadap perilaku tokoh yang tepat pada masa itu (harafiah), misalnya perintah ALLAH memusnahkan orang-orang tertentu dalam PL., agar tidak ditiru pada masa kini. Teladan yang ditiru dalam kegiatan seperti itu adalah ketaatan tokoh terhadap perintah TUHAN. Bukan praktek membunuh atau menikahi wanita sundal oleh Hosea.

Ketiga, apa responsku? $?^{35}$

a. Ucapan Syukur? Maksud dari respons ini adalah ungkapan syukur dari pembaca yang berkenaan dengan pesan yang ditemukan pada bagian sebelumnya.

b. Doa? Kegiatan dari respons ini adalah menaikkan doa untuk diri sendiri atau orang lain yang berkenaan langsung dengan pesan pada bagian sebelumnya. Bisa saja temuan pesan di bagian sebelumnya berkenaan dengan tindakan untuk mendoakan diri sendiri atau orang lain yang tepat.

${ }^{35}$ Ongkowidjojo, "Theological Interpretation Of Scripture; Suatu Pengantar," 49. Pada bagian ini penting untuk memberikan aplikasi yang sesuai dengan pesan nats. Seturut dengan Prinsip Theological Intepretation, Ongkowidjojo menegaskan bahwa aplikasi dari satu hasil penafsiran Kitab Suci memberikan indikasi yang menentukan terhadap kebenaran suatu tafsiran sesuai dengan maksud kepenulisannya, lebih dalam dari sekadar tujuan akhir. 
c. Mengakui dosa? Kegiatan dari respons ini adalah membuka diri dengan pengakuan yang jujur atas tingkah laku, perangai yang bertentangan dengan temuan pesan nats pada bagian sebelumnya. Pembaca hendaknya jujur akan pelanggaran itu agar dibawa dalam respon ini kepada Allah dengan mengakui pelanggaran-pelanggaran dimaksud. Bagian ini memberikan ruang koreksi diri bagi pembaca dan memohon ampun dosa kepada Allah.

d. Tekad. Kegiatan dari respons ini adalah merancang satu aksi nyata dalam lingkup tertentu meskipun lingkup terkecil misalnya keluarga atau seseorang. Merancang dan melaksanakan pesan Firman TUHAN pada lingkup terkecil jauh lebih baik daripada merancang tanpa tindakan nyata.

4. Berdoa. Mohon Allah memberdayakan agar pembaca melakukan firmanNya

Dari formula diatas, maka saatnya akan menemukan makna dari Mazmur 12 dengan pendekatan teks sesuai genrenya yakni mazmur ratapan. Pemaknaan yang dimaksud peneliti dalam tulisan ini adalah dengan menggunakan pola BGA.

\section{Pemaknaan Mazmur 12}

Kebanyakan mazmur ditulis oleh Daud, tetapi ada juga oleh penulis lain. Kadang Daud bukan menuliskan tetapi orang lain menuliskan dan mengabdikannya kepada Daud (Mazmur untuk Daud). Mazmur dinyanyikan dengan iringan musik masa lalu (gambus, kecapi, seruling dll.). Mazmur ditulis sepagi Musa (Mazmur 90) dan pada zaman kerajaan, dan masa pembuangan (Mazmur 137) bahkan sekemudian paska pembuangan (Mazmur 126). Mazmur 12 ditulis oleh Daud guna dinyanyikan para pemimpin biduan.

Sebagai satu jenis sastra, ratapan (lament, bhs Arab Ritsâ) masih terus terdengar hingga sekitar tahun 650 atau disebut juga masa Jahiliya di Arab. Genre 
Ritsâ dalam sastra Arab adalah satu syair merefleksikan rasa sedih, rasa turut berdukacita karena itu genre ini disebut sebagai syair ratapan. Syair ratapan ini kemudian berkembang kepada (digubah) sebagai ungkapan hati seseorang terhadap yang lain atas bela sungkawa dari kejadian yang menyedihkan misalnya karena perang. ${ }^{36}$ Menurut Nur Hamim, kondisi perang menjadi suatu pemandangan pada era itu selain sebagai pembuktian kekuatan antar individu, perang adalah politik yang dipakai dalam kabilah-kabilah pada masanya yang kemudian perang ini beralih menjadi sebuah budaya sekaligus melengkapi rutinitas kehidupan sosialnya. ${ }^{37}$ Situasi sosial ini menjadi salah satu frame yang dibutuhkan untuk memahami kata-kata seperti "penindasan" dan "memberi keselamatan "(ay.6), serta "menjaga kami” (ay.9).

Tabel 2 Langkah tafsir langkah ketiga Renungkanlah dengan butir a) apa saja yang kubaca

\begin{tabular}{|l|l|}
\hline $\begin{array}{l}\text { Per- } \\
\text { tama }\end{array}$ & $\begin{array}{l}\text { Genre Mazmur atapan } \\
\text { Kesejajaran yang ada diantaranya; } \\
\text { a) Orang saleh telah habis=telah lenyap orang-orang setia } \\
\text { (ay.2) } \\
\text { b)Bibir yang manis=lidah yang bercakap besar (ay.4) } \\
\text { c) Orang-orang yang lemah=orang miskin (ay.6) } \\
\text { d)Janji TUHAN adalah murni (ay.7a)=TUHAN yang } \\
\text { akan menepatinya (ay.8a) } \\
\text { e) Identifikasi bahasa gambaran (imagery), yang ada } \\
\text { diantaranya; } \\
\text { f) Bibir yang manis, bibir yang bercabang (ay.3) } \\
\text { g)Bagaikan perak yang teruji (ay.7a) }\end{array}$ \\
\hline $\begin{array}{l}\text { Ke- } \\
\text { dua }\end{array}$ & $\begin{array}{l}\text { Pemazmur mengalami perubahan mood dari meratap } \\
\text { karena rasa kuatir (ay.1-6a), kemudian timbul perasaan } \\
\text { keyakinan bahwa TUHAN akan menolong. Namun pada } \\
\text { ayat 9 ratapan muncul kembali karena "orang-orang } \\
\text { fasik" masih ada di mana-mana, kebusukkan juga terus } \\
\text { bercokol diantara anak manusia }\end{array}$ \\
\hline
\end{tabular}

${ }^{36}$ Nur Hamim dkk., "Syair Ratapan (RITSÂ) dan Cinta (Ghazal) Dalam Budaya Perang Bangsa Arab Jahiliyah (Kajian Sosiologi Sastra)," Nur Hamim 336 Nuansa 9, no. 2 (2012): 340.

${ }^{37}$ Hamim dkk., 350. 


\begin{tabular}{|c|c|}
\hline $\begin{array}{l}\mathrm{Ke}- \\
\text { tiga }\end{array}$ & $\begin{array}{l}\text { Keluhan pemazmur, yang ada diantaranya; } \\
\text { a) Orang saleh telah habis (ay.2) } \\
\text { b)Lenyap orang-orang yang setia (ay.2) } \\
\text { c) Banyak orang berkata dusta dan bibir bercabang (ay.3) } \\
\text { d)Penindasan kepada orang yang lemah dan miskin (ay.6) } \\
\text { Perasaan yang dialami, yang ada diantaranya; } \\
\text { Ada rasa takut, kekuatiran karena maraknya dusta, bibir } \\
\text { manis dan penindasan }\end{array}$ \\
\hline $\begin{array}{l}\text { Ke- } \\
\text { empat }\end{array}$ & $\begin{array}{l}\text { Apa saja yang kita baca tentang TUHAN Allah? } \\
\text { a) Dalam perikop ini Allah akan bangkit menyelamatkan } \\
\text { umatNya (ay.6b) } \\
\text { b) TUHAN punya janji murni, akan menepati janji-jani- } \\
\text { Nya (ay.7-8) } \\
\text { c) Selalu menjaga umatNya (ay.8b) }\end{array}$ \\
\hline
\end{tabular}

\section{Pesan yang ditemukan}

Dalam konsepsi iman Israel di Perjanjian Lama telah lama mengenal YWHH sebagai tempat mengadu, perlindungan, atau seperti istilah 'kota benteng' dan 'semesta alam.' Ungkapan ini menjadi satu kepuasan tersendiri sebagai ekses Monotheisme di dalam YHWH. Karena ada keyakinan bahwa kesalahankesalahan (dosa) menjadi penyebab berbagai penindasan yang dialami. Desti Samarenna menyatakan juga bahwa pengalaman Israel bersama Allah menghadapi intimidasi bangsa-bangsa lain memberi keyakinan yang makin kuat bahwa Allah juga akan menyelamatkan umatNya dari penindasan-penindasan selanjutnya dari kaum fasik dan orang berdosa. ${ }^{38}$ Keyakinan ini menjadi penghiburan disaat orang-orang baik dan orang-orang yang setia habis dan lenyap diantara mereka. Ada perasaan takut namun ada keyakinan yang kokoh berdasarkan pengalaman bersama Allah.

Pesan lain dalam Mazmur 12 berupa pengajaran kepada pembaca agar tetap yakin dengan TUHAN. Karena Dia adalah Allah yang tidak pernah ingkar

38Desti Samarenna, "Tinjuan Teologi ‘Allah Kota Benteng' Dalam Mazmur 46:1-12," PASCA : Jurnal Teologi dan Pendidikan Agama Kristen, 2019, 19, https://doi.org/10.46494/psc.v15i2.53. 
janji. Dengan sifat atau karakter Allah yang tidak ingkar janji, menyelamatkan umat yang berseru-seru, memberi konfirmasi agar seseorang menghilangkan keraguan terhadapNya. Berbagai perilaku orang fasik dan melawan moral yang weolah tampak dalam sisi kemenangan, bukanlah kekalahan bagi orang benar dihadapan Allah. Dalam penelitiannya tentang perilaku immorality dalam kisahkisah di Alkitab, Iman Hawala menegaskan bahwa Allah akan memberikan penghukuman kepada siapa saja yang berlaku immoral pada masa hidupnya. Dalam pada itu Allah juga akan menunjukkan kebenaran dan kekudusanNya dengan cara dan waktuNya pula. ${ }^{39}$ Hamba-hamba Tuhan patut memegang pesan ini dengan yakin, karena Ia menyebut manusia dengan hambaKu dan umat pilihanKu. Ia mencurahkan berkat dan RohNya agar hambaNya tetap percaya kepadaNya bahkan berkat-berkatNya diberikan secara melimpah tanpa memandang kita miskin atau kaya, berapa banyak dosa yang diperbuat sebelumnya seperti orang Israel. ${ }^{40}$ Karena berkat itu akan diberikanNya ketika umatNya kembali dan berseru kepadaNya.

Dalam lintasan sejarah Israel, beriman kepada Allah yang Satu dan Esa telah dilakoni umat Israel sampai pada pembuangan dan pasca pembuangan. Bukti nyata itu terlihat dari catatan 2 Raja-raja 23. Raja Yosia menemukan bukti keimanannya ketika bait Allah Yerusalem saat dibersihkan setelah lebih dari 300 tahun digunakan untuk pemujaan kepada Allah. ${ }^{41}$ Hingga masa kini bukti ini patut

39 Iman Kristina Halawa, "IMMORALITY: SEBUAH STUDI BIBLIKAL-SISTEMATIS," Manna Rafflesia 6, no. 1 (2019): 61, https://doi.org/10.38091/man raf.v6i1.110.

40Hasahatan Hutahaean, "Memahami 'Menjadi Saksi' Tafsir Struktur Yesaya 44:1-8," dalam Menabur Kasih Menuai Jiwa, ed. oleh Stenly R Paparang (Jakarta: Departemen Literatur dan Media Arastamar (Delima), 2016), 181.

${ }^{41}$ Marthin Steven Lumingkewas, "One God Or One Lord? Deuteronomi And The Meaning Of Monotheism," Fidei: Jurnal Teologi Sistematika dan Praktika 2, no. 2 (2019): 410. 
untuk dipegang bagi pembaca Mazmur dari berbagai latar belakang. Tidak terkecuali pembaca Mazmur pada masa kini.

\section{Respons Terhadap Pesan Yang Ditemukan}

Pembaca pada masa kini dapat menarik pesan ini dengan melakukan hal-hal yang tepat dan terukur. Tindakan seperti ucapan Syukur, doa, mengakui dosa, dan tekad untuk melakukan sesuatu dapat diberikan sesuai kondisi iman seseorang.

Ucapan syukur; dengan melihat kebesaran Allah yang tidak membalaskan kejahatan dengan kejahatan. Bersyukur karena TUHAN yang sabar dan baik itu tidak pernah ingkar janji. Janji Allah adalah menyelamatkan orang berdosa yang berseru padaNya. Dalam konteks pandemik covid-19 sejak pertengahan Pebruari 2020 lalu, ungkapan syukur akan terasa ketika masih menikmati pangan setiap hari, serta diberi kekebalan (immune tubuh) yang prima dalam menghadapi ganasnya virus covid-19 jenis baru itu (SARS-CoV-2; severe acute respiratory syndrome coronavirus-2). ${ }^{42}$

Berdoa; meminta kepada Allah agar memberikan kendali penuh dalam hidup pembaca. Meminta kepada Roh Kudus untuk mengubah orang-orang bibir manis dan lidah yang bercakap besar berubah, bertobat kembali pada Allah. Agar mereka kembali kepada Allah yang benar yang dikenal dalam Yesus Kristus. Kalis mengingatkan bahwa hanya ada satu Allah yang benar dalam Alkitab. ${ }^{43}$ Allah yang hidup dan benar itu telah mencipta alam semesta, menjadi Allah seluruh dunia, bangsa-bangsa dan Allah dari semua jiwa manusia yang pernah

\footnotetext{
42 Hasahatan Hutahaean, Bonnarty Steven Silalahi, dan Linda Zenita Simanjuntak, "Spiritualitas Pandemik: Tinjauan Fenomenologi Ibadah DI Rumah," Evangelikal: Jurnal Teologi Injili dan Pembinaan Warga Jemaat 4, no. 2 (2020): 238, https://doi.org/10.46445/ejti.v4i2.270.

${ }^{43}$ Kalis Stevanus, "Karya Kristus Sebagai Dasar Penginjilan di Dunia Non-Kristen," Fidei: Jurnal Teologi Sistematika dan Praktika 3, no. 1 (2020): 3.
} 
ada.

Mengaku dosa; dosa yang dikerjakan dalam segmen seperti yang tertulis dalam pesan, yang sering adalah pengingkaran kemahakuasaan Allah atas hidup seseorang. Kepada sebagian orang yang memiliki tingkat pengetahuan yang tinggi serta tingkat perhitungan dan prediksi yang tinggi acapkali terjerumus pada mengandalkan kemampuan diri sendiri. Allah menjadi oknum yang tidak perlu diandalkan. Ini adalah dampak lain dari hikmat yang diberikan Allah kepada manusia. Padahal dengan hikmat, "menusia memiliki kecakapan praktis dengan kemampuan melakukan tindakan dan bertutur kata yang tepat pada situasi dan kondisi yang beragam." ${ }^{44}$ Kecakapan tersebut menyangkut kemampuan untuk menghindari sekaligus untuk menangani masalah. Namun demikian menempatkan Allah dalam segala rencana dan kemampuan seseorang adalah sisi utama sebagai umat pilihan Allah. Pertobatan disini penting, karena menjadi kunci pemulihan spiritual seseorang untuk menjadi dan menuju serupa dengan Kristus. ${ }^{45}$ Pertobatan ini harus berkelanjutan, hingga memberikan formasi spiritual yang kokoh dan mampu mengalahkan keinginan daging. ${ }^{46}$

Pembacaan dengan metode BGA telah di tahap menemukan pesan teks dan makna disertai panduan perbuatan terhadap pesan. Penelitian ini menarik untuk dilanjutkan dalam penelusuran kitab Mazmur dengan genre ratapan lainnya. Menurut Villanueva dalam disertasinya (kemudian diterbitkan dalam bentuk buku, dengan judul yang sama), terdapat 62 pasal mazmur dengan genre ratapan

${ }^{44}$ Hasahatan Hutahaean, "Hikmat dan Hidup Sukses," Didaskein 3 No.2 (2015): 34.

${ }^{45}$ Hengki Wijaya, "Pertobatan di Dalam Philokalia: Artikel Ulasan," DUNAMIS: Jurnal Penelitian Teologi dan Pendidikan Kristiani 3, no. 1 (2018): 56, https://doi.org/10.30648/dun.v3i1.

46Wijaya, 60. 
di kitap Mazmur. ${ }^{47}$ Keterbatasan eksplorasi keindahan Mazmur Ratapan hanya dari Mazmur 12 tidak dapat dihindari dari segi sisi-sisi lainnya. Misalnya cakupan penggambaran (imagery) yang beraneka ragam di mazmur ratapan lainnya.

\section{KESIMPULAN}

Mazmur 12 sebagai mazmur ratapan diakhiri dengan ratapan. Perubahan mood kembali ke ratapan setelah sebelumnya pemazmur sempat bersukacita oleh karena Allah yang menepati janji dengan menyelamatkan manusia. Pemazmur kembali meratap sebab orang-orang fasik masih muncul dalam pemantauanya meski Allah datang bertindak. Orang-orang fasik muncul dengan perilaku kebusukkan yang ada padanya sehingga sebagian umat Allah mengalami dampaknya. Meski umat Allah masih meratap namun di dalam diri meyakini janji Allah. Segenap orang Kristen yang mengalami kisah perasaan yang sama dengan pemazmur 12 patut kembali teguh dalam Kristus. Dunia yang tidak berubah sepanjang masa dengan banyaknya orang-orang busuk, berbibir manis, lidah bercabang serta pelaku penindasan menuntut orang Kristen sadar bahwa hikmat bijaksana dari Tuhan harus mengubah pola diri merespons ancaman dari dunia. Allah berkarya bagi keselamatan manusia tidak bergantung kepada masih ada atau tidaknya orang-orang fasik dan perilaku kebusukkan di bumi ini. KaryaNya ada oleh karena diriNya sendiri dengan didasarkan kasih yang sedemikian besar bagi manusia. Sejak penetapan pandemik covid19 pertengahan Pebruari lalu di Indonesia jemaat mengalami nasib yang sama. Mulai dari beribadah di rumah, tidak dapat dengan bebas bertemu dengan sahabat, handai taulan, serta bersalaman dengan leluasa sesama anggota gereja dan juga anggota keluarga. Ada satu perubahan pola, paradigma terhadap kehidupan sehari-hari dan "ancaman baru terhadap spiritualitas" jemaat. Belum lagi adanya anggota jemaat yang kehilangan pekerjaan serta banyaknya mengalami pengurangan upah (salary). Perjalanan kekuatiran

${ }^{47}$ Federico G. Villanueva, The 'Uncertainty of a Hearing' : A Study of the Sudden Change of Mood in the Psalms of Lament (Leiden: Brill, 2008), 44, 49. 
ini masih belum menemukan titik terang hingga ditemukannya vaksin terhadap virus covid-19 jenis baru itu (SARS-CoV-2) itu. Dari Mazmur 12 ini umat TUHAN hendaknya tetap menaikkan pujian dan hormat kepada Dia yang dikenal dalam nama Yesus Kristus. Penelitian ini membutuhkan penelitian lanjutan dalam genre yang serupa dari Mazmur lainnya, sehingga gambaran Mazmur Ratapan kian lekat di hati orang Kristen karena literatur yang bertambah banyak. Tentu untuk memudahkan orang Kristen memahami isi hati Allah.

\section{DAFTAR PUSTAKA}

Adamo, David T. "Reading Psalm 23 in African Context." Verbum et Ecclesia 39, no. 1 (2018): 1-8. https://doi.org/10.4102/ve.v39i1.1783.

Balchin, John, Peter Cotterell, Mary Evans, Gilbert Kirby, Peggy Knight, dan Derek Tidball. Intisari Alkitab Perjanjian Lama. Jakarta: Scripture Union Indonesia, 2016.

Barus, Armand. Baca Gali Alkitab Genre: Mazmur Ratapan. Disunting oleh Restu A Santoso. Jakarta: Scripture Union Indonesia, 2019.

- Mengenal Tuhan Melalui Penderitaan. Jakarta: Scripture Union Indonesia, 2015.

Barus, Armand, Hans Wuysang, dan Rimawaty Panjaitan. Panduan Pelatihan Baca Gali Alkitab. Jakarta: Scripture Union Indonesia, 2015.

Botha, Philippus J. "Interpreting 'torah' in psalm 1 in the light of psalm 119." HTS Teologiese Studies / Theological Studies 68, no. 1 (2012): 1-7. https://doi.org/10.4102/hts.v68i1.1274.

Budhi, Samgar Setia. "Eksegesis Mazmur 73: Pergumulan Orang Benar Tentang Kemakmuran Orang Fasik." HUPERETE S 1, no. 1 (2019): 1-16.

Danandjaja, James. "Metode Penelitian Kepustakaan." Antropologi Indonesia 0, no. 52 (15 Juli 2014): 82-92. https://doi.org/10.7454/ai.v0i52.3318.

Drane, John. Memahami Perjanjian Lama III. Disunting oleh Barnabas Ludji. Ketiga. Jakarta: Scripture Union Indonesia, 2017.

Halawa, Iman Kristina. "IMMORALITY: SEBUAH STUDI BIBLIKALSISTEMATIS." Manna Rafflesia 6, no. 1 (2019): 53-73. https://doi.org/10.38091/man_raf.v6i1.110. 
Hamim, Nur, Dosen Iain, Sultan Maulana, dan Hasanudddin Banten. "Syair Ratapan (RITSÂ) dan Cinta (Ghazal) Dalam Budaya Perang Bangsa Arab Jahiliyah (Kajian Sosiologi Sastra)." Nur Hamim 336 Nuansa 9, no. 2 (2012): 335-52.

Hamzah, Amir. Metode Penelitian Kepustakaan. Revisi. Malang: Literasi Nusantara, 2020.

Harsono, Nitis. "Tugas Manusia dalam Dunia Milik Tuhan." Fidei: Jurnal Teologi Sistematika dan Praktika 3, no. 1 (2020): 110-25. https://doi.org/10.34081/fidei.v3i1.95.

Hutahaean, Hasahatan. "Hikmat dan Hidup Sukses." Didaskein 3 No.2 (2015): 33-41.

. "Memahami 'Menjadi Saksi' Tafsir Struktur Yesaya 44:1-8." Dalam Menabur Kasih Menuai Jiwa, disunting oleh Stenly R Paparang, 171-82. Jakarta: Departemen Literatur dan Media Arastamar (Delima), 2016.

_. Pangimpola Na; Pemahaman Nats-nats Almanak Dengan Pendekatan Metode BGA. Medan: Prodi Teologi STTSU, 2017.

Hutahaean, Hasahatan, Bonnarty Steven Silalahi, dan Linda Zenita Simanjuntak. "Spiritualitas Pandemik: Tinjauan Fenomenologi Ibadah DI Rumah." Evangelikal: Jurnal Teologi Injili dan Pembinaan Warga Jemaat 4, no. 2 (2020): 234-49. https://doi.org/10.46445/ejti.v4i2.270.

Kirchberger, Georg. Allah Menggugat Sebuah Dogmatik Kristiani. Kedua. Maumere: Ledalero, 2012.

Lumingkewas, Marthin Steven. "One God Or One Lord? Deuteronomi And The Meaning Of Monotheism." Fidei: Jurnal Teologi Sistematika dan Praktika 2, no. 2 (2019): 388-410.

Maleachi, Martus Adinugraha. "Karakteristik dan Berbagai Genre dalam Kitab Mazmur." Veritas : Jurnal Teologi dan Pelayanan 13, no. 1 (2012): 12140. https://doi.org/10.36421/veritas.v13i1.250.

Margaret, Carmia. "Pendekatan Interpretasi Teologis Kitab Suci dan PrasuposisiPrasuposisi Teologis di Baliknya." Veritas : Jurnal Teologi dan Pelayanan 18, no. 2 (2019): 141-60. https://doi.org/10.36421/veritas.v18i2.330.

Ongkowidjojo, Hendry. "Theological Interpretation Of Scripture; Suatu Pengantar." Amanat Agung 9 (1) (2013): 35-56.

Osborne, Grant R. Spiral Hermeneutika: Pengantar Komprehensif bagi Penafsiran Alkitab. Surabaya: Momentum, 2012.

Redaksi Scripture Union Indonesia. "Santapan Harian.” Jakarta: Scripture Union Indonesia, 2020. 
Samarenna, Desti. 'Tinjuan Teologi 'Allah Kota Benteng' Dalam Mazmur 46:112.” PASCA : Jurnal Teologi dan Pendidikan Agama Kristen, 2019. https://doi.org/10.46494/psc.v15i2.53.

Smoak, Jeremy D. "Amuletic inscriptions and the background of YHWH as guardian and protector in Psalm 12." Vetus Testamentum 60, no. 3 (2010): 421-432. https://doi.org/10.1163/156853310X504856.

Stevanus, Kalis. "Karya Kristus Sebagai Dasar Penginjilan di Dunia NonKristen." Fidei: Jurnal Teologi Sistematika dan Praktika 3, no. 1 (2020): $1-19$.

Vanhoozer, Kevin J. "First Theology: God, Scripture \& Hermeneutics." Pro Ecclesia: A Journal of Catholic and Evangelical Theology 13, no. 3 (2004): 362-64. https://doi.org/10.1177/106385120401300309.

Villanueva, Federico G. The 'Uncertainty of a Hearing' : A Study of the Sudden Change of Mood in the Psalms of Lament. Leiden: Brill, 2008.

Wicaksono, Arif. "KETIKA ALLAH 'DIAM': ANALISIS RETORIKA AYUB 39:4-15." Evangelikal: Jurnal Teologi Injili dan Pembinaan Warga Jemaat 2, no. 2 (2018): 135-46.

Wijaya, Hengki. "Pertobatan di Dalam Philokalia: Artikel Ulasan." DUNAMIS: Jurnal Penelitian Teologi dan Pendidikan Kristiani 3, no. 1 (2018): 5273. https://doi.org/10.30648/dun.v3i1. 